\title{
Purification of mouse primordial germ cells by Nycodenz
}

\author{
T. Mayanagi ${ }^{1 *}$, R. Kurosawa ${ }^{1}$, K. Ohnuma ${ }^{2}$, A. Ueyama ${ }^{3}$, K. Ito ${ }^{1}$ and J. Takahashi ${ }^{1}$ \\ ${ }^{1}$ Laboratory of Animal Science, Faculty of Agriculture, Iwate University, Ueda Morioka-shi Iwate \\ 020-8550, Japan; ${ }^{2}$ Department of Life Science, Institute of Life Science and Medicine, 3154 Yakushiji, \\ Minamikawachi-machi Kawachi-gun, Tochigi 329-0431, Japan; and ${ }^{3}$ Centre for Instrument Analysis, \\ Iwate University, Ueda Morioka-shi Iwate 020-8550, Japan
}

Primordial germ cells are important cells for the study of germ cell lineage. It has proved difficult to obtain highly purified primordial germ cells for preparation of a specific antibody. In the present study, a new method for purifying mouse primordial germ cells was developed using a Nycodenz gradient. Furthermore, the polyclonal anti-mouse primordial germ cells IgG derived from mouse primordial germ cells was prepared. As this IgG reacted only with primordial germ cells obtained at day 12.5 after mating, this antibody appeared to recognize the stagespecific antigen of primordial germ cells. One reason that a continuous primordial germ cell marker has not been obtained is because the purity of the primordial germ cells used has been too low to prepare the antibody. This new method represents a significant improvement in the purification of primordial germ cells; it is simpler than previous methods, and produced mouse primordial germ cells with a purity of more than $95 \%$. In addition, the separation reagent Nycodenz is non-toxic and achieved separation of primordial germ cells without attachment of antibodies against the primordial germ cell membrane surface. This new purification method and stage-specific antibody will be useful for the analysis of the mechanisms of primordial germ cell migration.

\section{Introduction}

Mouse primordial germ cells (PGCs) are derived from a small population of embryonic ectoderm cells at the egg cylinder stage (Lawson and Hage, 1994). About 100 PGCs are identified with the alkaline phosphatase (ALP) in extra-embryonic mesoderm of embryos at day 7 after mating and they reach the genital ridge with proliferation and migration by day 13.5 after mating (Ginsberg et al., 1990). At this time, the number of PGCs increases to about 25000 (Minz and Russell, 1957; Tam and Snow, 1981). Most studies have used markers such as ALP activity and antibody bound to PGCs.

It is clear that PGCs are detected using these markers, but the markers are not specific for PGCs. ALP activity is generally used for the identification of mouse PGCs. However, ALP staining detects not only PGCs, but also other somatic cells. In addition, monoclonal antibodies such as SSEA-1 (Solter and Knowles, 1978), 4C9 (Yoshinaga et al., 1991), TG-1 (Beverley et al., 1980) and ACK-2 (Nishikawa et al., 1991) were used to detect mouse PGCs. Similarly, these monoclonal antibodies do not identify antigens of PGC specificity, because these antibodies were not derived from mouse PGCs. Recently, it was reported that green fluorescent protein

*Present address: Kannondai Terrace House E-101, 1-9-9, Kannondai, Tsukuba-shi, Ibaraki 305-0856, Japan

Email: ohnuma@affrc.go.jp
(GFP) expressing PGCs of Oct-4/GFP transgenic mice were first detected as early as day 8 after mating at the base of allantois in living embryos (Yoshimizu et al., 1999). However, expression of this protein was temporary. These non-specific or temporary expressions prevent the continuous tracing of PGCs. Therefore, a marker that is expressed consistently during germ line is required.

Some studies have reported attempts to purify PGCs. PGCs containing 10-20\% somatic cells were obtained by the Percoll gradient method (De Felici and McLaren, 1982; De Felici, 1998). However, Percoll has a low toxicity (Brysk et al., 1981). In addition, mouse PGCs were purified by the mini magnetic cell sorting (MACS) system (De Felici and Pesce, 1995; De Felici, 1998) and the immunoaffinity purification method (De Felici and Pesce, 1995; De Felici, 1998). The antibody used with these methods was TG-1 monoclonal IgM. The antigen of TG-1 antibody was the glycoprotein fraction of thymus cells (Beverley et al., 1980). Therefore, it did not specifically react with mouse PGCs. PGCs were purified from fluorescence-activated cell sorting (FACS) (McCarrey et al., 1987) and tissue non-specific ALP-positive cells of $A \mathrm{kp} 2^{\text {tm1Sor }}$ mutant mouse embryos expressing lacZ (beta-galactocidase) using FACS of $\beta$-gal expressing cells (FACS-gal) (Abe et al., 1996). However, this method used tissue non-specific ALP to purify PGCs, and a large amount of PGCs could not be obtained using FACS. 


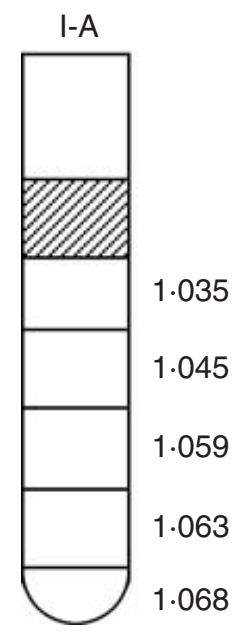

$\left(\mathrm{g} \mathrm{ml}^{-1}\right)$

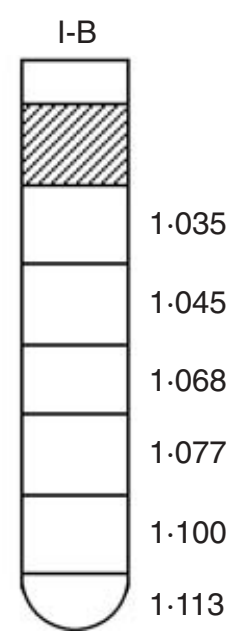

$\left(\mathrm{g} \mathrm{ml}^{-1}\right)$

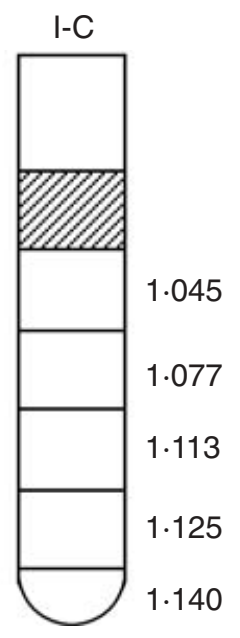

$\left(\mathrm{g} \mathrm{ml}^{-1}\right)$

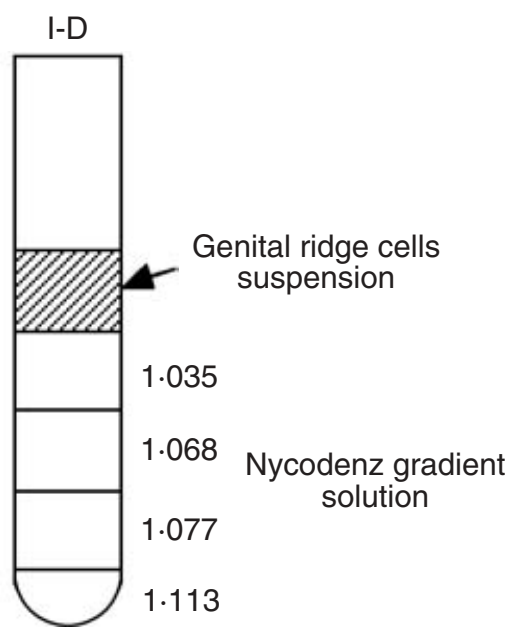

$\left(\mathrm{g} \mathrm{m}^{-1}\right)$

Fig. 1. The four methods for purification of mouse primordial germ cells (PGCs) (method I). Mouse PGCs were purified by four methods; I-A, I-B, I-C and I-D. Each Nycodenz solution was prepared with PBS and each fraction was added in $1 \mathrm{ml}$ layers from high to low density. Furthermore, genital ridge cells suspension was layered on the Nycodenz gradient and centrifuged.

In the present study, the authors sought to establish a purification method for mouse PGCs using a Nycodenz gradient. This reagent is not cytotoxic and has a low viscosity (Rickwood et al., 1982). Nycodenz has been used to separate blood cells (Bøyum and Scand, 1976). Nycodenz is 5-[N-(2,3-dihydroxypropyl)acetamido]2, 4, 6 -triiodo- $N, N^{\prime}$-bis(2,3-dihydroxypropyl)isophthalamide. An attempt was made to produce the anti-mouse PGCs IgG by using the PGCs obtained with this method.

\section{Materials and Methods}

Mice and embryos

ICR/Jcl mice were used in this study; they were bred by Clea, Japan, Inc. (Shizuoka). The adult female mice (2 or 3 months of age) were placed with male mice overnight. The mice were kept in a closed colony with $12 \mathrm{~h}$ light: $12 \mathrm{~h}$ dark cycle at $23^{\circ} \mathrm{C}$. The day on which a vaginal plug was found was defined as day 1 after mating. Female mice were killed at day 12.5 after mating by dislocation of the cervical spine and embryos were collected in phosphate buffered saline (PBS; Cosmo Bio Corporation, Tokyo) in tissue culture dishes (Terumo, Tokyo).

\section{Collection of genital ridge cells}

Genital ridge was obtained from the urogenital complex (mesonephros and genital ridge) as described by Cooke et al. (1993). Genital ridges were separated from mesonephros by fine needles (23G; Terumo) and collected in PBS. Genital ridge cells were disaggregated by pipetting in a $1.5 \mathrm{ml}$ Eppendorf tube (Strstedt Aketiengesellschaft and Corporation, Numbrecht).
Disaggregated genital ridge cells were resuspended in $1 \mathrm{ml}$ of PBS.

\section{Separation of PGC by Nycodenz gradient (method I)}

The separation methods of mouse PGCs are shown (Fig. 1). Four different methods; I-A to -D consisting of different Nycodenz (Sigma Chemical Co., St Louis, $\mathrm{MO})$ gradient solutions were used to purify mouse PGCs. Each method consisted of four or five different Nycodenz gradient concentrations, respectively: I-A: 1.035, 1.045, 1.059, 1.063 and $1.068 \mathrm{~g} \mathrm{ml}^{-1}$; I-B: $1.035,1.045,1.068$, $1.077,1.100$ and $1.113 \mathrm{~g} \mathrm{ml}^{-1}$; I-C: $1.045,1.077,1.113$, 1.125 and $1.140 \mathrm{~g} \mathrm{ml}^{-1}$; and I-D: $1.035,1.068,1.077$ and $1.113 \mathrm{~g} \mathrm{ml}^{-1}$. Each gradient solution was layered in each test tube (external diameter $15.4 \mathrm{~mm}$ ) from high to low density. These tubes were centrifuged at $300 \mathrm{~g}$ for $15 \mathrm{~min}$ at $4^{\circ} \mathrm{C}$. Each layer including PGCs or somatic cells was collected, and washed three times. The number of PGCs was counted with double staining of ALP and 4C9 monoclonal antibody staining. 4C9 monoclonal antibody was donated by T. Muramatsu (Nagoya University). The dye exclusion test was carried out with $0.5 \%$ Trypan blue (Wako Pure Chemicals, Osaka) to estimate viability of separated PGCs.

\section{Staining of PGCs}

Double staining with ALP and 4C9 monoclonal antibody identified PGCs. Cell suspensions were swabbed on glass slides and air-dried. They were fixed in $0.01 \%$ $(\mathrm{v} / \mathrm{v})$ acetic acid (Wako), 10\% (v/v) formaldehyde (Wako), and $90 \%(\mathrm{v} / \mathrm{v})$ methanol (Wako) for $5 \mathrm{~s}$ and washed with running water. ALP staining was performed at $37^{\circ} \mathrm{C}$ 
for $2 \mathrm{~h}$ as described by Brinster and Hastard (1977) with naphthol AS-MX phosphate (Sigma) as substrate and Fast blue RR salt (Sigma). After washing and airdrying, 4C9 monoclonal antibody diluted $\times 200$ was applied on to the glass slides. The monoclonal antibody was detected with the biotinylated anti-rat Ig (Pharmacia Biotech, Uppsala) as the secondary antibody, and with streptoavidin horseradish peroxidase (Pharmacia Biotech) and the peroxidase detection staining kit (POD; Wako).

\section{Observation of separated mouse PGCs by scanning electron microscopy}

PGCs reached genital ridges at about day 12.5 after mating, and PGCs changed to a colonization form. The morphological surface structure of PGCs was observed using scanning electron microscopy (SEM). After the purification by Nycodenz gradient, collected cells were fixed by $1 \%(\mathrm{v} / \mathrm{v})$ glutaraldehyde (Sigma) for $30 \mathrm{~min}$. The cells were washed with 0.1 mol phosphate $\mathrm{I}^{-1}$ buffer $(\mathrm{pH} 7.4)$ and cell suspension was applied on to a small piece of glass slide, which was treated with poly-L-lysine (Wako) to allow attachment of the cells to it. Cells on the slide were dehydrated by serial ethanol dehydration and transferred to an isoamyl acetate (Wako) bath and dried using the critical point dryer (HCP-1; Hitachi Ltd, Tokyo). They were coated with Au using IB-3 (Hitachi). Cells were observed using SEM (S-2500; Hitachi).

\section{Preparation of anti-mouse PGC polyclonal antibody}

Mouse PGCs purified by Nycodenz gradient method were injected into an ear vein of Japanese White rabbits (Oryctolagus cuniculus var. domesticus; Oriental Bio Service Kanto Ltd, Tsukuba) six times at an interval of 13 weeks. The total number of mouse PGCs injected was $1.1 \times 10^{7}$ cells. One week after the final immunization, antibody titre was confirmed and $150 \mathrm{ml}$ of blood was obtained. The antiserum was separated by centrifugation at $1000 \mathrm{~g}$ for $30 \mathrm{~min}$ and inactivated at $56^{\circ} \mathrm{C}$ for $30 \mathrm{~min}$. About $70 \mathrm{ml}$ of antiserum was obtained and dispensed into small aliquots, stored at $-40^{\circ} \mathrm{C}$. Anti-mouse PGC IgG was purified from antiserum by salting out with $33 \%$ $(\mathrm{w} / \mathrm{v})$ saturated ammonium sulphate (Wako). The IgG in the precipitation was confirmed by sodium dodecyl sulphate polyacrylamide gel electrophoresis (SDS-PAGE) by the method described by Laemmli (1970) and it was stained with Coomassie brilliant blue (quick-CBB; Wako). A part of the anti-mouse PGC IgG fraction was concentrated by Ultra Free 15 (Millipore Corporation, Bedford, MA) and dialysed against $0.1 \mathrm{~mol} \mathrm{NaCl} \mathrm{I}^{-1}$ in $0.25 \mathrm{~mol} \mathrm{NaHCO} \mathrm{I}^{-1}$ buffer ( $\mathrm{pH}$ 9.0) to bind fluorescein isothiocyanate (FITC: Nutritional Biochemicals Corporation, Cleveland, $\mathrm{OH}$ ). The FITC was added to the dialysis of the anti-mouse PGCs IgG fraction and reacted overnight at $4^{\circ} \mathrm{C}$. After the reaction, anti-mouse
PGC conjugated FITC was dialysed against PBS and free FITC was removed by gel filtration with Sephadex G-25 (Pharmacia Biotech). The degree of purification of antimouse PGC IgG-conjugated FITC was analysed using the SMART system (Pharmacia Biotech): the absorbance of protein $(280 \mathrm{~nm})$ and FITC $(495 \mathrm{~nm})$ were measured and the ratio was calculated to estimate the mole fraction bound. The purified anti-mouse $\lg \mathrm{G}$ was used to observe the reactivity for mouse tissue sections.

\section{Detection of mouse PGCs by anti-mouse PGC IgG-FITC}

(i) Reaction of anti-mouse PGC IgG to isolated mouse $P G C$ s. Genital ridge cells obtained from mice at day 12.5 after mating were collected by the Nycodenz gradient method. These cells were fixed with $1 \%$ glutaraldehyde (Wako) for $1 \mathrm{~h}$. These fixed cells were washed three times with PBS. Anti-mouse PGC IgG-FITC ( $\times 1000$ dilution) was added and this solution was left in the dark for $1 \mathrm{~h}$. The treated cells were washed to remove free IgG and layered on to a glass slide and were observed by fluorescence microscopy (AX-80T, Olympus Promarketing, Inc., Tokyo).

(ii) Reaction of anti-mouse PGC IgG to mouse embryo sections. Testes and ovaries were obtained from the adult mice. Embryos were obtained from mice at day 11.5, $13.5,15.5$ or 17.5 after mating. These samples were fixed in acetone (Wako) at $4^{\circ} \mathrm{C}$ for 3-7 days. After fixation, embryos and gonads were dehydrated in $100 \%$ ethanol at $4^{\circ} \mathrm{C}$ for 3-7 days, immersed in xylene (Wako) and embedded in paraffin wax (Wako). The embedded tissues were sectioned at $6 \mu \mathrm{m}$ thickness. Each section was double-stained by immunostaining and ALP staining. At this time, ALP staining was carried out as described by Gomori (1939). Immunostaining with anti-mouse PGC IgG was carried out using ALP staining. The sections were reacted with anti-mouse PGC IgG (antibody titre was $\times 1000$ ) in the dark for $1 \mathrm{~h}$. The free antibody was removed by washing. The sections were dehydrated by an ethanol series and xylene (Wako) and were sealed with Canada balsam (Wako). The sections were then observed by fluorescence microscopy.

\section{Improvement of PGC purification method (method II)}

The purification methods of mouse PGCs are shown (Fig. 2). For purification of mouse PGCs, three methods were carried out, II-A to -C, with Nycodenz gradient solutions as described for method I. Each method consisted of two to three different concentrations of Nycodenz: II-A: 1.035, 1.068, $1.113 \mathrm{~g} \mathrm{ml}^{-1}$ (each layer was $1 \mathrm{ml}$ ); II-B: $1.035,1.068,1.113 \mathrm{~g} \mathrm{ml}^{-1}$ (the $1.068 \mathrm{~g} \mathrm{ml}^{-1}$ layer was $2 \mathrm{ml}$ and the other layers were $1 \mathrm{ml}$ ); II-C: $1.035,1.113 \mathrm{~g} \mathrm{ml}^{-1}$ (the $1.035 \mathrm{~g} \mathrm{ml}^{-1}$ layer was $1 \mathrm{ml}$ and $1.113 \mathrm{~g} \mathrm{ml}^{-1}$ layer was $3 \mathrm{ml}$ ). Each gradient solution was layered in each test tube from high to low density. These tubes were centrifuged at $300 \mathrm{~g}$ for $15 \mathrm{~min}$ 


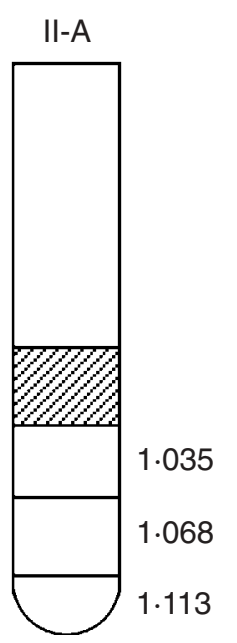

$\left(\mathrm{g} \mathrm{ml}^{-1}\right)$

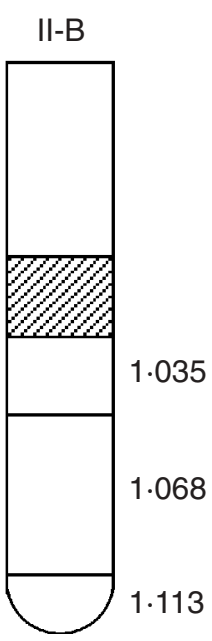

$\left(\mathrm{g} \mathrm{ml}^{-1)}\right.$

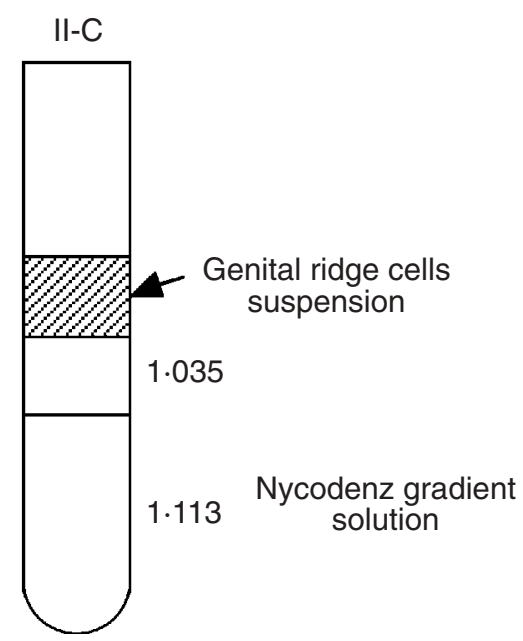

$\left(\mathrm{g} \mathrm{ml}^{-1}\right)$

Fig. 2. The three methods for purification of mouse primordial germ cells (PGCs) (method II). Mouse PGCs were purified by three methods: II-A, II-B and II-C. Each Nycodenz solution was prepared with PBS and layered from high to low density. Furthermore, the genital ridge cell suspension was layered on the Nycodenz gradient and centrifuged.

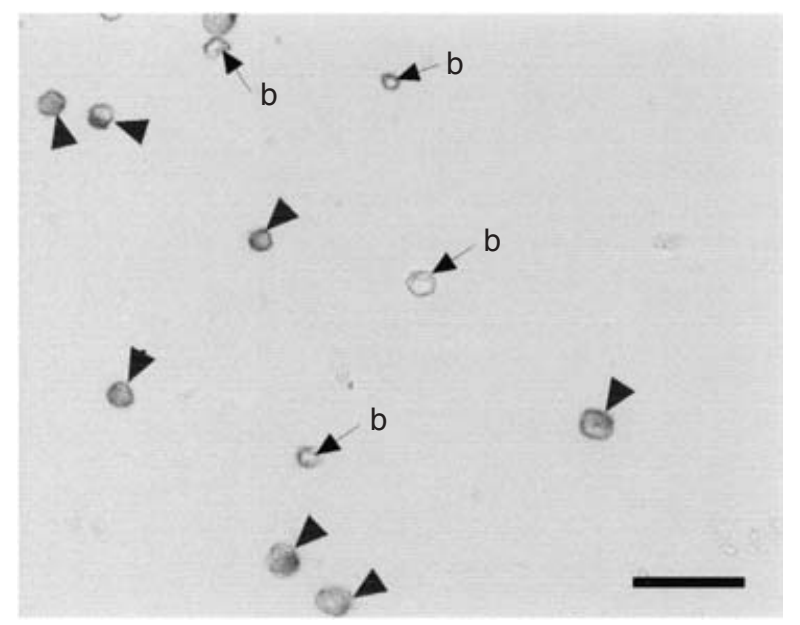

Fig. 3. Mouse genital ridge cells at day 12.5 after mating before purification stained by double stain (alkaline phosphatase (ALP) and 4C9 monoclonal antibody). Arrowheads: ALP and 4C9 positive cells identified as primordial germ cells, b: ALP and 4C9 negative cells. Scale bar represents $50 \mu \mathrm{m}$.

at $4^{\circ} \mathrm{C}$. Each layer was collected and washed three times. The number of PGCs was counted with double staining of ALP and 4C9 and the dye exclusion test was carried out.

\section{Statistical analysis}

In this study, the number of mouse PGCs was expressed as the mean $\pm \mathrm{SD}$. The statistical analysis was carried out using Student's $t$ test. Significance was set at $P$ $<0.05$. Experiments were carried out at least in triplicate.

\section{Results}

\section{Purification of PGCs by Nycodenz gradient}

There were many PGCs and other somatic cells in the genital ridge cell suspension before purification (Fig. 3). PGCs were stained blue-brown, but the other somatic cells were not stained. The percentages of PGCs and numbers of PGCs per fetus in each Nycodenz gradient layer are shown (Table 1). Approximately $53.4 \pm 10.35 \%$ of the total number of cells were PGCs in the genital ridges before purification and there were $32.6 \pm 18.6 \times$ $10^{3}$ PGCs per fetus. After purification, the concentration of the Nycodenz gradient included PGCs and the highest ratios for the methods I-A to I-D were 1.068, 1.113, 1.045 and $1.035 \mathrm{~g} \mathrm{ml}^{-1}$, respectively. The highest percentages of the purification methods for I-A to I-D were $63.2 \pm$ $15.4 \%, 63.3 \pm 29.1 \%, 65.4 \pm 14.9 \%$, and $80.2 \pm 5.3 \%$, respectively. These results indicated that mouse PGCs could be purified on $1.035 \mathrm{~g} \mathrm{ml}^{-1}$ Nycodenz gradient by method I-D. At this time, the number of PGCs obtained was $5.1 \pm 2.5 \times 10^{2}$ cells per fetus. In all experiments, viability of separated PGCs was more than $80 \%$.

\section{Observation of PGCs by scanning electron microscopy}

Photographs of PGCs obtained by method I-D using SEM are shown (Fig. 4). Spherical cells with a diameter of 10-15 $\mu \mathrm{m}$ were observed in the layer with $1.035 \mathrm{~g}$ Nycodenz $\mathrm{ml}^{-1}$. The cells had many convexoconcave and pseudopodium-like processes on the surface (Fig. 4). 


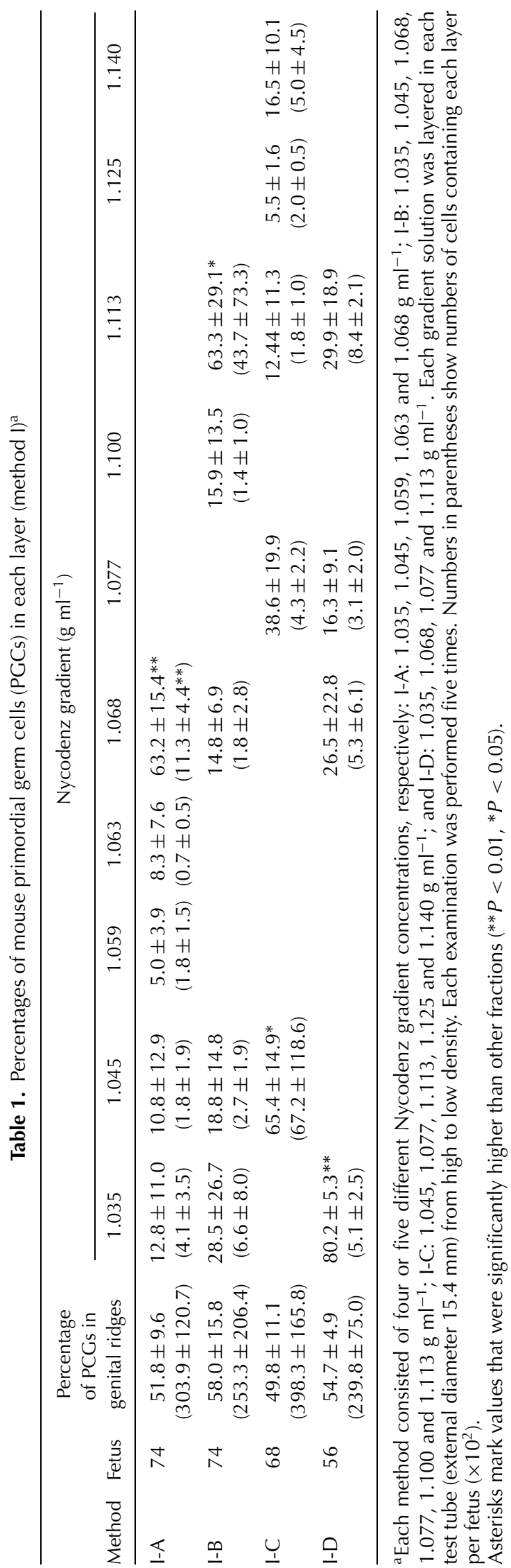

In the layer with $1.068 \mathrm{~g} \mathrm{Nycodenz} \mathrm{ml}^{-1}$, some spherical cells with a diameter of 10-15 $\mu \mathrm{m}$ were observed; however, there were very few cells in the layer with $1.077 \mathrm{~g}$ Nycodenz $\mathrm{ml}^{-1}$. There were many erythrocytes and some spherical cells with a diameter of $7 \mu \mathrm{m}$ in the layer with $1.113 \mathrm{~g}$ Nycodenz $\mathrm{ml}^{-1}$.

\section{Detection of mouse PGCs with anti-mouse PGCs IgG-FITC}

After purification, anti-mouse PGCs IgG was confirmed as a band of mass $150 \mathrm{kDa}$ using SDS-PAGE (data not shown). For an absorbance of $280 \mathrm{~nm}$ and $495 \mathrm{~nm}$, the established mole fraction of FITC-conjugated antimouse PGCs IgG was 2.91.

(i) Reaction of anti-mouse PGC $\lg G$ to purified mouse $P G C s$. PGCs dissociated from the genital ridge were detected as the reaction of anti-mouse PGC IgG with FITC (Fig. 5). Almost all spherical cells with a diameter of 10$15 \mu \mathrm{m}$ expressed green fluorescence so that anti-mouse PGCs IgG reacted with them. Somatic cells and blood cells reacting with anti-mouse PGCs IgG-FITC were not observed. Therefore, it was indicated that anti-mouse PGCs IgG specifically bound to spherical cells with a diameter of 10-15 $\mu \mathrm{m}$.

(ii) Reaction of anti-mouse PGC IgG to mouse embryo sections. The antibody titre of anti-mouse PGC $\lg$ G was $1 \times 10^{3}$. Anti-mouse PGC IgG detected PGCs in embryos at only day 12.5 after mating (Fig. 6). Cells that reacted with anti-mouse PGCs IgG were also observed in a part of the brain. In embryos and adult tissues at day 15.5 after mating, anti-mouse PGC IgG did not detect PGCs (data not shown). However, ALP staining detected PGCs in genital ridges as dark-brown cells at days $11.5,12.5$ and 15.5 after mating. ALP staining could not detect germ cells in the testis and ovary tissues.

\section{Improvement of the PGC purification method}

Percentages and numbers of PGCs per fetus in each Nycodenz gradient layer method II are shown (Table 2). Before purification, genital ridge cell suspension contained many PGCs and other somatic cells (Fig. 3). PGCs were stained blue-brown, but the somatic cells were not stained. Approximately $59.8 \pm 10.6 \%$ of the total cells were PGCs in genital ridges before being purified and the number of PGCs was $24.5 \pm 15.3 \times 10^{3}$ cells per fetus. After the purification, the concentration of the Nycodenz gradient layer including PGCs with the highest ratio among all the methods was $1.035 \mathrm{~g} \mathrm{ml}^{-1}$. The highest percentages of purification by the three methods were $\mathrm{II}-\mathrm{A}(92.9 \pm 3.2 \%), \mathrm{II}-\mathrm{B}(95.2 \pm 3.4 \%)$ and II-C $(90.0 \pm$ $5.5 \%$ ). Each percentage of PGC obtained from separated fractions was based on the number of cells contained in each fraction being $100 \%$. These results indicated that mouse PGCs could be purified most efficiently by method II-B. PGCs purified by method II-B are shown (Fig. 7). 

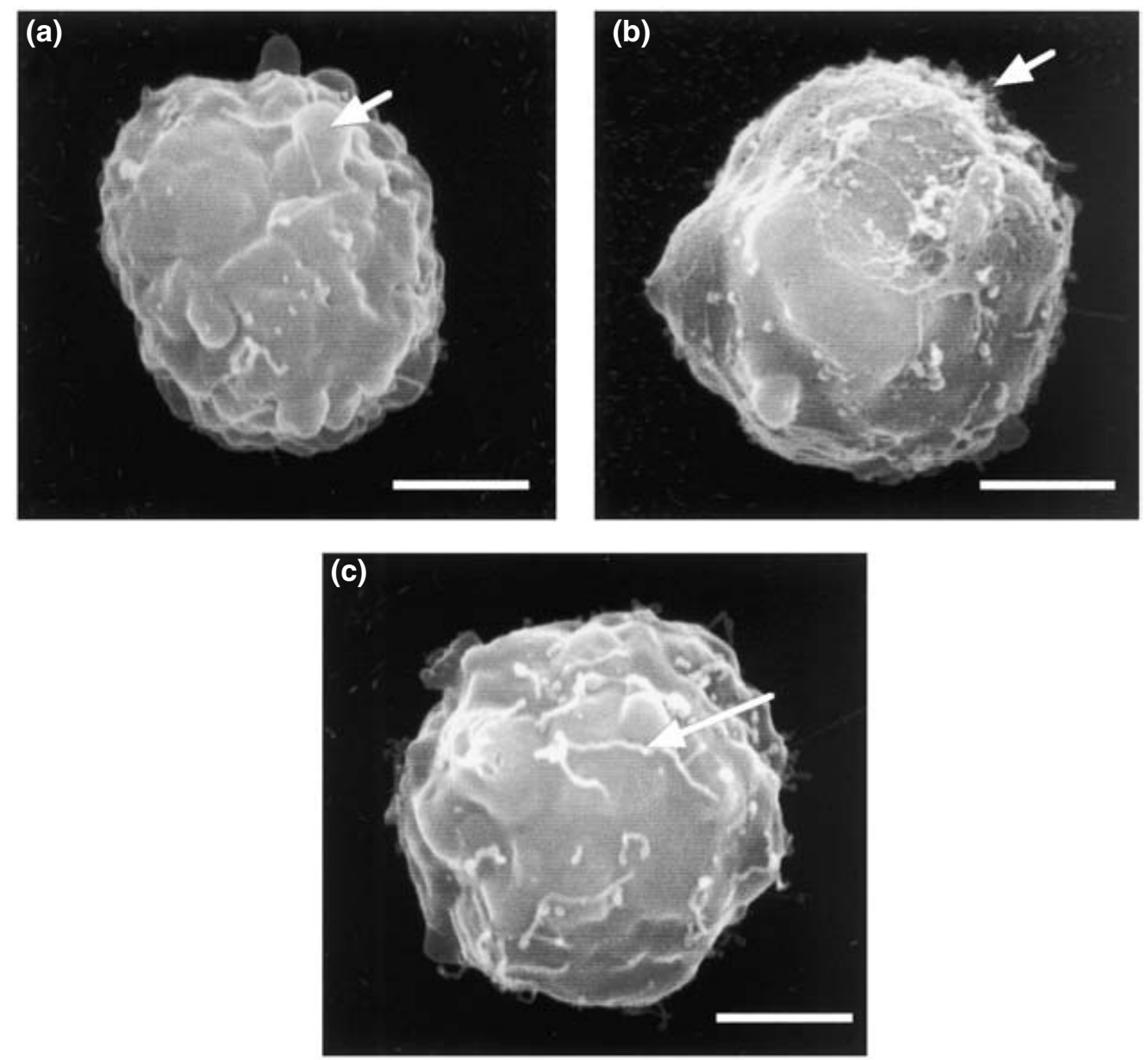

Fig. 4. Mouse primordial germ cells (PGCs) purified by method I-D and observed in the layer with $1.035 \mathrm{~g}$ Nycodenz $\mathrm{ml}^{-1}$. These PGCs were large spherical cells with surface characteristics such as convexoconcave and pseudopodium-like processes (arrows). Scale bars represent $5 \mu \mathrm{m}$.

Table 2. Percentages of mouse primordial germ cells (PGCs) in each layer (method II)

\begin{tabular}{|c|c|c|c|c|c|}
\hline \multirow[b]{2}{*}{ Method } & \multirow[b]{2}{*}{ Fetus } & \multirow{2}{*}{$\begin{array}{l}\text { Percentage of PGCs } \\
\text { in genital ridge cells }\end{array}$} & \multicolumn{3}{|c|}{ Nycodenz gradient $\left(\mathrm{g} \mathrm{ml}^{-1}\right)$} \\
\hline & & & 1.035 & 1.068 & 1.113 \\
\hline II-A & 42 & $\begin{array}{l}67.6 \pm 2.2 \\
(17.6 \pm 10.5)\end{array}$ & $\begin{array}{l}92.9 \pm 2.2 \\
(2.3 \pm 3.2)\end{array}$ & $\begin{array}{c}60.6 \pm 30.4 \\
(1.1 \pm 0.9)\end{array}$ & $\begin{array}{c}32.5 \pm 22.4 \\
(2.3 \pm 3.8)\end{array}$ \\
\hline II-B & 38 & $\begin{array}{c}54.4 \pm 18.3 \\
(21.5 \pm 12.6)\end{array}$ & $\begin{array}{c}95.2 \pm 3.4^{* *} \\
(1.4 \pm 0.6)\end{array}$ & $\begin{array}{r}29.9 \pm 23.1 \\
(2.1 \pm 4.0)\end{array}$ & $\begin{aligned} 21.2 & \pm 21.1 \\
(3.4 & \pm 6.7)\end{aligned}$ \\
\hline II-C & 54 & $\begin{array}{l}57.4 \pm 9.0 \\
(34.5 \pm 22.9)\end{array}$ & $\begin{array}{c}90.0 \pm 5.5^{* *} \\
(4.3 \pm 6.1)\end{array}$ & - & $\begin{array}{l}5.2 \pm 2.4 \\
(0.1 \pm 0.1)\end{array}$ \\
\hline
\end{tabular}

${ }^{\mathrm{a}}$ Each method consisted of two to three different concentrations of Nycodenz: II-A: 1.035, 1.068 and $1.113 \mathrm{~g} \mathrm{ml}^{-1}$ (each layer was $1 \mathrm{ml}$ ); II-B: $1.035,1.068$ and $1.113 \mathrm{~g} \mathrm{ml}^{-1}$ (the $1.068 \mathrm{~g} \mathrm{ml}^{-1}$ layer was $2 \mathrm{ml}$ and the other layers were $1 \mathrm{ml}$ ); II-C: $1.035 \mathrm{and} 1.113 \mathrm{~g} \mathrm{ml}^{-1}$ (the $1.035 \mathrm{~g} \mathrm{ml}^{-1}$ layer was $1 \mathrm{ml}$ and $1.113 \mathrm{~g} \mathrm{ml}^{-1}$ layer was $3 \mathrm{ml}$ ). Each gradient solution was layered in each test tube from high to low density. Each examination was performed three times. Numbers in parentheses show numbers of cells containing each layer per fetus $\left(\times 10^{3}\right)$.

**Value was significantly higher than other fractions $(P<0.01)$. 
PGCs were observed as spherical cells with a diameter of about $20 \mu \mathrm{m}$. At that time, the number of PGCs obtained was $1.4 \pm 0.6 \times 10^{3}$ cells per fetus. In all experiments, the viability of PGCs was more than $80 \%$.

\section{Discussion}

This study established a new purification method for mouse PGCs by Nycodenz, and the preparation of antimouse PGC antibody using purified PGCs. This antibody reacted only to mouse PGCs at day 12.5 after mating.

Monoclonal antibodies reacting to mouse PGCs, such as SSEA-1 (Solter and Knowles, 1978), 4C9 (Yoshinaga et al., 1991), TG-1 (Beverley et al., 1980) and antiForssman antibody (Karol et al., 1981) have been reported. Certainly, these monoclonal antibodies are able to identify mouse PGCs. However, these monoclonal antibodies do not react only with PGCs. In the present study, 4C9 monoclonal antibody was able to detect mouse PGCs. However, as 4C9 monoclonal antibody reacted with other somatic cells of mesonephros, it was suggested that tracing PGCs during migration in embryo tissues with these monoclonal antibodies would be difficult because these antibodies are derived from other cells and not from PGCs. These antibodies were produced from F9 teratocarcinoma cells (Yoshinaga et al., 1991) or thymus cells (Beverley et al., 1980) as antigens; however, PGCs have never been used as an antigen.

Antibodies derived from PGCs have never been prepared because of the lack of an efficient method of purifying PGCs. A more efficient method for purification of mouse PGCs has been developed in the present study. Some purification methods of mouse PGCs have been reported using Percoll, FACS (McCarrey et al., 1987; Abe et al., 1996) or MACS (Pesce and De Felici, 1995; De Felici, 1998). The Percoll method is based on the density of cells, and cells were collected without binding antibodies. However, the Percoll method may result in cytotoxicity during purification (Rickwood et al., 1982). However, the methods using MACS were used for the reaction of cell-surface antigen and antibody. The advantage of these methods in practice is the high purification of PGCs. However, these methods must use antibody, which may coat antigens, making the removal of the antibody difficult after binding. In the present study, PGCs were purified by the Nycodenz gradient method and the antibody against the PGC surface antigen was prepared without any apparent problems. As a result, in method I-D, mouse PGC could be obtained with more than $80 \%$ purity. This method does not use antibodies and allows purification while maintaining the cell surface antigens.

The antibody immunized with the PGCs antigen purified by method I-D in the present study recognized mouse PGCs obtained at day 12.5 after mating, but it
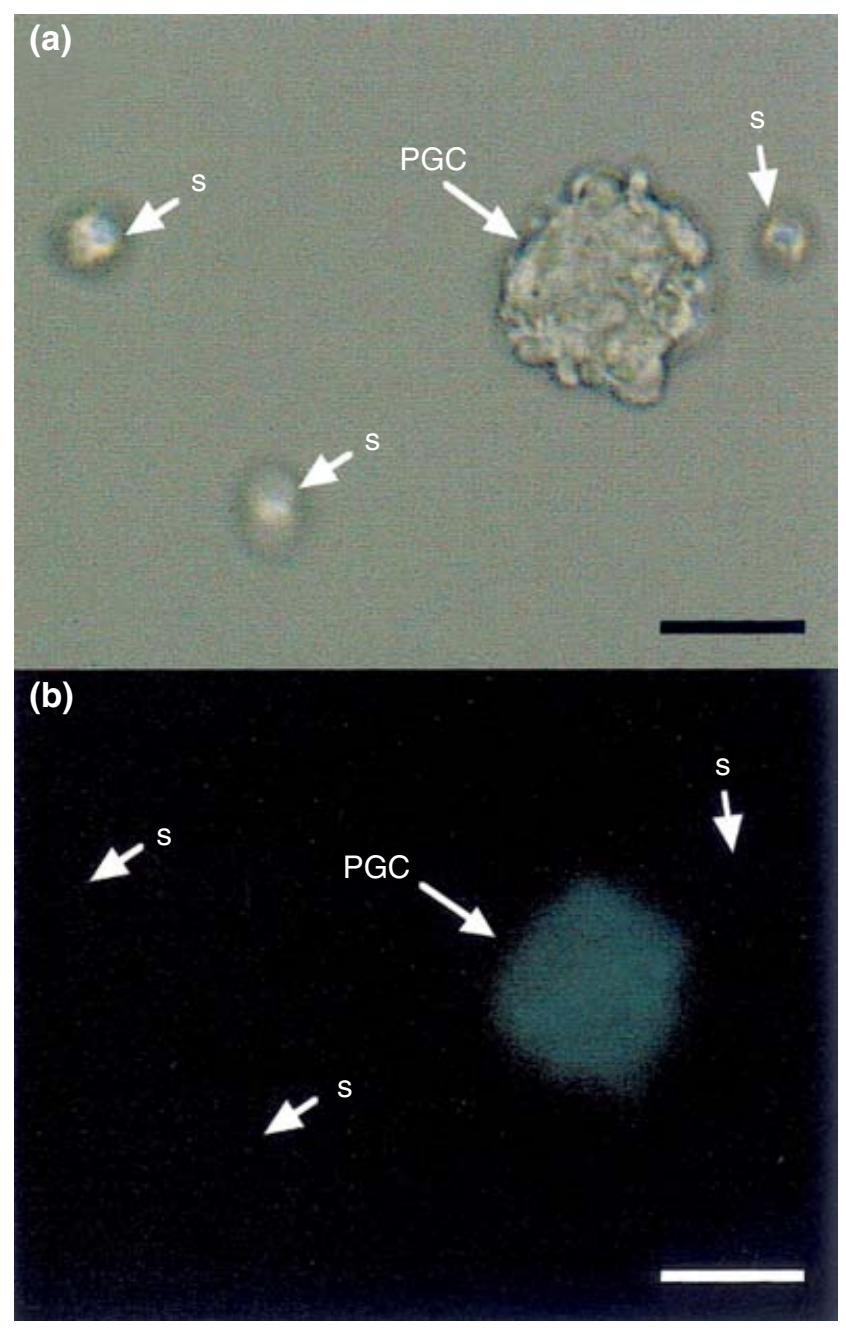

Fig. 5. Mouse genital ridge cells at day 12.5 after mating reacted with anti-mouse primordial germ cell (PGC) IgG-fluorescein isothiocyanate (FITC). Mouse PGCs expressed green fluorescence that indicated that anti-mouse PGC IgG-FITC $(\times 1000)$ reacted with mouse PGCs. The other somatic cells (s) did not react. (a) Light microscopy and (b) fluorescence microscopy. Scale bars represent $10 \mu \mathrm{m}$.

was not able continuously to recognize them during gametogenesis. It is thought that this result occurred for the following possible reasons: (1) PGCs might not consistently express the same antigen during gametogenesis stages or the expression of the antigen might be extremely low; (2) the purity of PGCs might be too low to obtain a suitable antibody; and (3) the specificity of antibody might be too low or the amount of the specific antibody produced might be too small.

One possible reason was that purity of PGCs was too low to prepare the antibody. Therefore, in the present study, the purification methods of PGCs were improved and further simplifed by the Nycodenz gradient method. It was possible to obtain mouse PGCs at day 12.5 after mating with a purity of more than $95 \%$ with method II-B. 


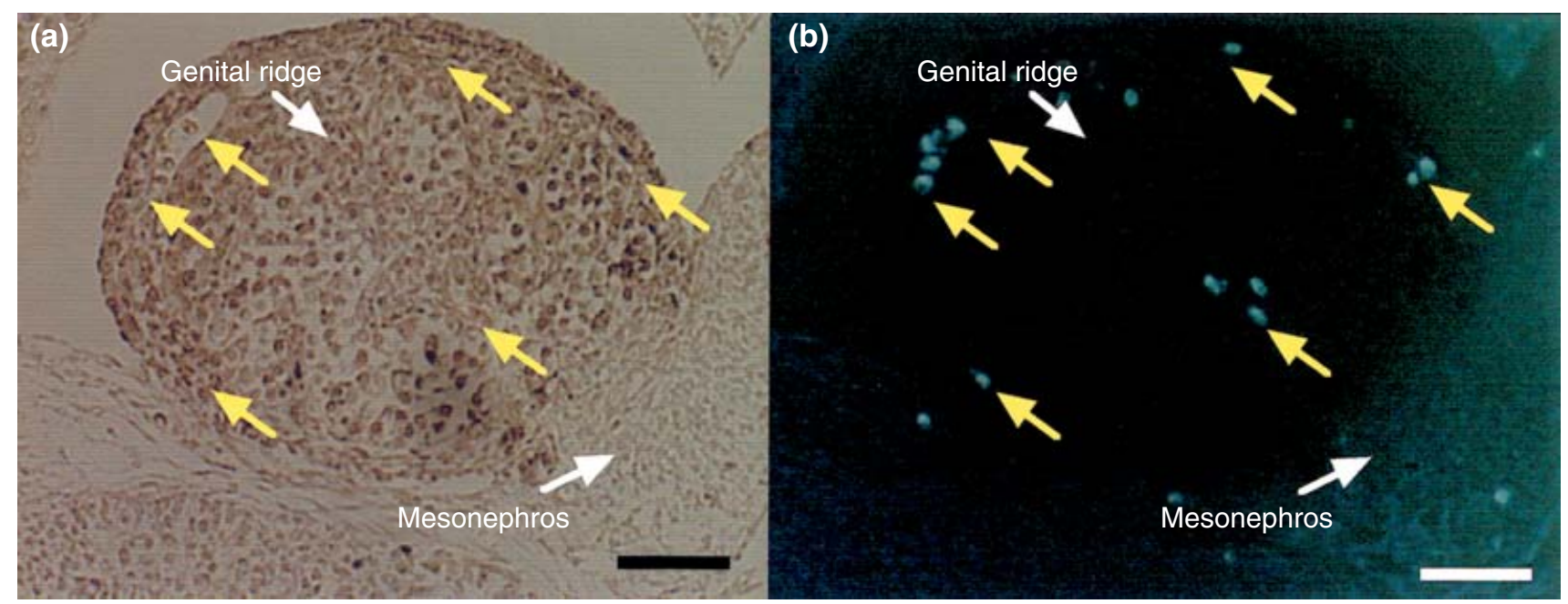

Fig. 6. Mouse primordial germ cells (PGCs) from mouse embryo sections at day 12.5 after mating reacted by double staining. Mouse embryos at day 12.5 after mating were double-stained (alkaline phosphatase (ALP) and immunostained with anti-mouse PGCs IgGfluorescein isothiocyanate (FITC)). PGCs were detected by both stain, arrows show stained PGCs. (a) PGCs were stained to dark brown by ALP staining in light microscopy. (b) PGCs expressed the green fluorescence by immunostaining in fluorescence microscopy. Scale bars represent $100 \mu \mathrm{m}$.

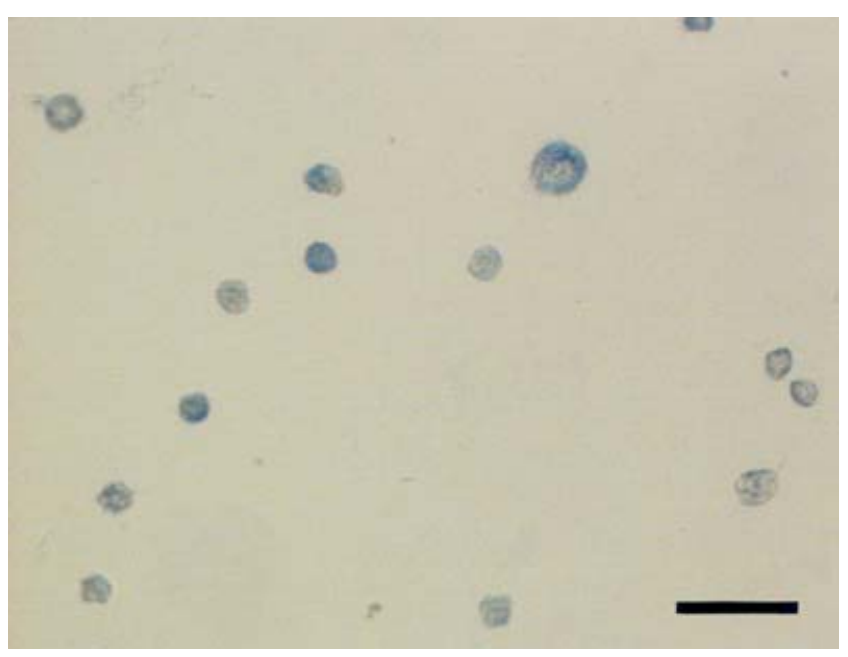

Fig. 7. Purified mouse primordial germ cells (PGCs) by method II-B in the layer with $1.035 \mathrm{~g}$ Nycodenz $\mathrm{ml}^{-1}$. Almost all cells stained blue-brown with double staining are identified as PGCs. Scale bar represents $50 \mu \mathrm{m}$.

This purity of PGCs was an improvement by about $15 \%$ compared with the result of method I-D, and higher than the results of Percoll, MACS, and the immunoaffinity purification method. In addition, Nycodenz, the separation reagent, was completely non-toxic (Rickwood et al., 1982), and this method could separate PGCs without attachment antibodies to the PGC cell membrane surface.

The results indicated that the Nycodenz gradient with three layers $\left(1.113,1.068\right.$ and $\left.1.035 \mathrm{~g} \mathrm{ml}^{-1}\right)$ in method
II-B was the most efficient in purifying mouse PGCs. Thus the number of PGCs in the genital ridge before separation at day 12.5 after mating was approximately 25000 , which was similar to the results of Tam and Snow (1981). After purification, PGCs were obtained at about 1400-5000 per fetus and 15000-50000 per experiment. It was possible to purify PGCs much more rapidly and with simpler equipment compared with the immunoaffinity or FACS methods. The entire process could be carried out in about $2 \mathrm{~h}$. Therefore, it is suggested that this purification method is useful for biochemical, morphological analysis and culture in vitro. However, the loss of PGCs in this study was greater compared with MACS or FACS. The reason for this may be that the characterization of PGC varies in the genital ridges at day 12.5 after mating, because PGC changes from the migration form to the colonization form during development at this stage (Donovan et al., 1986); that is, the cell surface antigen and intracellular substances were changed when the PGCs reached the genital ridges. It is possible that these changes of PGC were affected by their specific gravity. Actually, almost all the PGC markers reported previously recognized proteins or genes expressed temporarily in PGCs. This finding indicates that cell surface antigen and genes expressed in PGC were changes that accompanied the form and function of each developmental stage.

In the present study, the specific gravity of PGC was $1.035-1.068 \mathrm{~g} \mathrm{ml}^{-1}$, which is similar to that of tumour cells (Bosslet et al., 1981) and haematopoietic stem cells (Barker and McFarland, 1983). Tumour cells were reported to resemble stem cells in some aspects. Antigen of SSEA-1 and 4C9 monoclonal antibody reacted with 
PGCs derived from teratocarcinoma cells (Solter and Knowles, 1978; Yoshinaga et al., 1991). These antibodies react with the inner cell mass of early embryos. It was shown that these monoclonal antibodies reacted with cells that have high proliferation activity or totipotency. ALP activity was used to identify embryonic stem (ES) cells (Pease et al., 1990) and embryonic carcinoma (EC) cells (Nicolas et al., 1976). ES cells and EC cells have pluripotency and high ability for proliferation. Therefore, tumour cells, stem cells and undifferentiated cells proliferate greatly, and consequently they may have similar character. In the present study, the prepared antibody derived from mouse PGCs by the Nycodenz separation method reacted specifically with embryo PGCs at day 12.5 after mating. Anti-mouse PGC IgG also reacted with germ cells temporarily, and did not react continuously during its germ line. It was thought that anti-mouse PGC IgG was useful as a stage-specific marker at day 12.5 after mating.

In the present study, antibody was prepared that recognized PGCs at day 12.5 after mating. It is possible that this anti-mouse PGCs IgG and mouse PGCs obtained by this new purification method at day 12.5 after mating can be used for the analysis of cell surface antigens expressing PGCs and the mechanisms of PGC migration.

The authors thank P. Langman for his kind assistance with the preparation of the paper.

\section{References}

Abe K, Hashiyama M, MacGregor G, Yamamura K and Abe K (1996) Purification of primordial germ cells from TNAP $\beta$-geo mouse embryos using FACS-gal Developmental Biology $180468-472$

Barker JE and McFarland EC (1983) A method to enrich mouse hematopoietic stem cells Blood 62 827-831

Beverley PC, Linch D and Delia D (1980) Isolation of human haematopoietic progenitor cells using monoclonal antibodies Nature $\mathbf{2 7 8}$ 332-333

Bosslet K, Ruffmant R, Altevogt P and Schirrmacher V (1981) A rapid method for the isolation of metastasizing tumor cells from internal organs with the help of isopycnic density-gradient centrifugation in percoll British Journal of Cancer 44 356-362

Bøyum A and Scand J (1976) Isolation of lymphocytes, granulocyte and macrophages Immunology 5 Supplement 9-15

Brinster RL and Harstad H (1977) Energy metabolism in primordial germ cells of the mouse Experimental Cell Research 109 111-117

Brysk MM, Snider JM and Smith EB (1981) Separation of newborn epidermal cells on discontinuous isokinetic gradients of PERCOLL Journal of Investigative Dermatology 77 205-209

Cooke JE, Godin I, Constant CF, Heasman J and Whlie CC (1993) Culture and manipulation of primordial germ cells. In Methods in Enzymology Vol. 225 pp 37-77 Ed. J Celis. Academic Press, Burlington

De Felici (1998) Isolation and culture of germ cells from the mouse embryo. In Cell Biology, A Laboratory Handbook Vol. 1 2nd Edn pp 73-85 Ed. J Celis. Academic Press, Burlington
De Felici M and McLaren A (1982) Isolation of mouse primordial germ cells Experimental Cell Research 142 476-482

De Felici $\mathbf{M}$ and Pesce $\mathbf{M}$ (1995) Immunoaffinity purification of migratory primordial germ cells Experimental Cell Research 216 277-279

Donovan PJ, Scott D, Cairns LA, Heasman J and Wylie CC (1986) Migratory and postmigratory mouse primordial germ cells behave differently in culture Cell $\mathbf{4 4}$ 831-838

Ginsberg M, Snow MHL and MacLaren A (1990) Primordial germ cells in the mouse embryo during gastrulation Development 110 521-528

Gomori G (1939) Microtechnical demonstration of phosphatase in tissue sections Proceedings of Society for Experimental Biology and Medicine 4223

Karol RA, Kundau SK and Marcus DM (1981) Immunochemical relationship between Forssman and globoside glycolipid antigens Immunological Communications 10 237-250

Laemmli UK (1970) Cleavage of structural proteins during the assembly of the head of bacteriophage T4 Nature 227 680-685

Lawson KA and Hage WJ (1994) Clonal analysis of the origin of primordial germ cells in the mouse. In Germline Development (Ciba Foundation Symposium 182) pp 68-84 Eds J Marsh and J Goode. John Wiley and Sons, New York

McCarrey JR, Hsu KC, Eddy EM, Klevecz RR and Bolen JL (1987) Isolation of viable mouse primordial germ cells by antibody-directed flow sorting Journal of Experimental Zoology 242 107-111

Minz B and Russell ES (1957) Gene-induced embryological modifications of primordial germ cells in the mouse Journal of Experimental Zoology 134 207-237

Nicolas JF, Avner P, Gaillard J, Guenet JL, Jakob H and Jacob F (1976) Cell lines derived from teratocarcinomas Cancer Research 36 4224-4231

Nishikawa S, Kusakabe M, Yoshinaga K, Ogawa M, Hayashi S, Kunisada T, Era T, Sakakura T and Nishikawa S (1991) In utero manipulation of coat color formation by a monoclonal anti-c-kit antibody: two distinct waves of c-kit-dependency during melanocyte development $E M B O$ Journal 10 2111-2118

Pease S, Braghetta P, Gearing D, Grail D and Williams RL (1990) Isolation of embryonic stem (ES) cells in media supplemented with recombinant leukemia inhibitory factor (LIF) Developmental Biology 141 344-352

Pesce M and De Felici M (1995) Purification of mouse primordial germ cells by miniMACS magnetic separation system Developmental Biology $\mathbf{1 7 0}$ $722-725$

Rickwood D, Ford TC and Graham J (1982) Nycodenz: a new nonionic iodinated density gradient medium Analytical Biochemistry 123 23-31

Solter D and Knowles BB (1978) Monoclonal antibody defining a stagespecific mouse embryonic antigen (SSEA-1) Proceedings National Academy of Sciences USA 75 5565-5569

Tam PP and Snow MHL (1981) Proliferation and migration of primordial germ cells during compensatory growth in mouse embryos Journal of Embryology and Experimental Morphology 64 133-147

Yoshimizu T, Sugiyama N, De Felici M, Yoem YI, Masuko K, Obinata M, Abe K, Scholer HR and Matsui Y (1999) Germline-specific expression of the Oct-4/green fluorescent protein (GFP) transgene in mice Development, Growth and Differentiation 41 675-684

Yoshinaga K, Muramatsu H and Muramatsu T (1991) Immunohistochemical localization of the carbohydrate antigen 4C9 in the mouse embryo: a reliable marker of mouse primordial germ cells Differentiation $\mathbf{4 8}$ $75-82$

Received 11 October 2002

First decision 21 November 2002.

Revised manuscript received 9 December 2002.

Accepted 13 January 2003. 